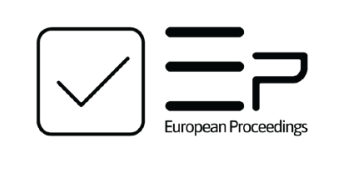

\author{
European Proceedings of \\ International Conference on Education \& \\ Educational Sciences \\ EPICEEPSY \\ e-ISSN: 2672-8141
}

www.europeanproceedings.com

DOI: $10.15405 /$ epiceepsy.20111.15

$11^{\text {th }}$ ICEEPSY 2020

The International Conference on Education \& Educational Psychology

\title{
COMPARISON OF THE VERBAL CATEGORY OF TENSE IN GERMAN AND ENGLISH
}

\author{
Jana Ondrakova (a)*, Vera Tauchmanova (b) \\ *Corresponding author \\ (a) University of Hradec Kralove, Faculty of Education, Rokitanskeho 62, Hradec Kralove, Czech Republic, \\ jana.ondrakova@uhk.cz \\ (b) University of Hradec Kralove, Faculty of Education, Rokitanskeho 62, Hradec Kralove, Czech Republic, \\ vera.tauchmanova@uhk.cz
}

\begin{abstract}
English has become the first foreign language taught at schools in the Czech Republic and the whole European Union. In comparison with other foreign languages taught at Czech schools, English seems relatively easy at the early stage of learning. Problems can arise when German, whose grammar system is much more complicated, is taught and learnt as the second foreign language. The text of the paper is based on previous research conducted at the Faculty of Education, University of Hradec Králové (Czech Republic), whose main objective was to find ways how to improve the effectiveness of teaching and learning English and German in the Czech educational environment. In the authors' point of view, it is necessary to make pre-service foreign language teachers aware of the fact that the knowledge, skills and experience which their learners acquired during the process of learning their first foreign language can be effectively used in the process of teaching and learning other foreign languages. This approach is nowadays taken not only by the authors of the text. The paper presents and comments on similarities and differences occurring in the system of Czech, English and German verb forms. The comments focus both on potential positive transfers and on negative impacts of language interference.
\end{abstract}

2672-8141 (c) 2020 Published by European Publisher.

Keywords: Foreign language learning and teaching, grammar tenses, English, German. 


\section{Introduction}

Teaching of foreign languages is a sphere which is paid a great attention to in the Czech Republic. English, the official language number one in the European Union, has also become the first foreign language for Czech school attendants. Using English, people can successfully communicate not only in Europe, but all over the world. Being aware of this fact, numerous young people have come to the opinion that their knowledge of English is sufficient for making themselves universally understood, and consequently they are no longer sufficiently motivated to learn other foreign languages. Andrášová (2012) draws attention to this fact when quoting Hufeisen and Krumm, who draw attention to young people's sharply declining motivation to learn other foreign languages, and who claim that "those individuals who began to learn English as their first foreign language often mistakenly believe that their foreign language communication skills are sufficient and that they do not need another foreign language for their lives. However, if students' first foreign language is not English, then they are sufficiently motivated to learn English as well”.

Talking about their students' motivation to learn the target foreign language, English teachers seem to be currently in an easier position than teachers of other foreign languages, for whom it seems necessary to look for new ways how to motivate their pupils to study other languages than English. Heinrichová (2017) sees a potential way of how to improve this situation in a wider use of the fiction written in the target language and in a careful selection of the teaching methods, because "it is important for a teacher to acquire methods based on students' own work. These techniques emphasize students' own thinking and problem solving” (p. 178). Also, Besedova (2017) tries to introduce innovative elements into teaching, she focuses on involvement of music in foreign language teaching. According to her, music plays an informative and formative role, it can activate and motivate pupils. "Simultaneously, it provides learners with effective practice of spoken language - pronunciation, rhythm, intonation and language fluency can be effectively practiced" (Besedova, 2017, p. 77). ${ }^{1}$

Knowledge and skills acquired during the process of acquisition and learning of their mother tongue are consciously and unconsciously transferred by learners into the process of learning their first foreign language. These skills, linguistic experience and knowledge are then applied to the system of another foreign language learnt afterwards. Andrášová (2012) makes a list of advantages occurring in the process of learning the second and further foreign languages - she mentions not only an older age and cognitive maturity, which help to make a better use of previously acquired learning strategies, but also knowledge of the Czech and English basic grammatical terminology. According to Andrášová, there is a significant connection between the ability to communicate in English and to communicate in German, because “....almost a half (43.9\%) out of those who speak good English speak good German as well. Conversely, more than a half (53.9\%) out of those who speak good German speak good English as well". According to the conclusion made in the research called "Foreign Language Competences of the Czech Population: German in Comparison with Other Languages”, which was published by Andrášová (2011) in the journal called Foreign Languages (2011, No. 4, p. 145), school children learning German as the first foreign

\footnotetext{
${ }^{1}$ Conclusions resulted from the research carried out by a team of experts from the University of Hradec Králové and the Faculty Hospital in Hradec Kralove prove that people actively involved in music reach better results in learning foreign languages (Besedova et al., 2019, pp. 1559-1567).
} 
language are then able to achieve better results in English than pupils with English as the first foreign language achieve subsequently in German.

Dziubalska-Kollaczyk (2017) claims that English is a "killer" of other languages, but simultaneously she claims that English as the first foreign language is becoming a means of learning other languages. She therefore symbolically refers to English as to the "father tongue".

Previously acquired language experience can have not only a positive impact on the process of learning other languages, but also a negative one, which is caused by the existing differences between the language systems. A list of negative phenomena existing in the process of learning the second foreign language definitely includes problems with pronunciation (the ability to imitate the pronunciation decreases with an increasing age, and, furthermore, the pronunciation typical of the mother tongue or the first foreign language has got automated), and also psychical factors, such as fear, feelings of embarrassment, etc.

\section{Problem Statement}

The difference between Czech, English and German is illustrated by the following Table 1, which compares and comments on the different constructions used in the given languages to express a semantically identical sentence.

Table 01. Czech, English and German versions of the same sentence ${ }^{2}$

\begin{tabular}{|l|l|l|}
\hline Czech & English & German \\
\hline Dám to chlapcum. & $\begin{array}{l}\text { I will give it to the boys. } \\
\text { I am giving it to the boys. } \\
\text { I am going to give it to the boys. }\end{array}$ & Ich gebe es den Jungen. \\
\hline $\begin{array}{l}\text { Dám } \\
\text { - the person is clear from } \\
\text { the verb form itself, no } \\
\text { personal pronouns / subject } \\
\text { is needed } \\
\text { - the future time is referred } \\
\text { to through the "present" } \\
\text { form of the verb }\end{array}$ & $\begin{array}{l}\text { - a personal pronoun / subject is } \\
\text { need to clarify the person } \\
\text { (all of them consist of an auxiliary } \\
\text { verb and a particular form of the full } \\
\text { verb }\end{array}$ & $\begin{array}{l}\text { Ich gebe } \\
- \text { a personal pronoun / subject } \\
\text { is needed to clarify the person } \\
- \text { present tense refers to the } \\
\text { future time }\end{array}$ \\
\hline $\begin{array}{l}\text { it } \\
\text { chlapcuim } \\
\text { the morphemic ending } \\
\text { Case and Number of the } \\
\text { noun }\end{array}$ & $\begin{array}{l}\text { to the boys } \\
- \text { Case is expressed through a } \\
\text { preposition and word order, } \\
\text {-Number is expressed through the } \\
\text { morphemic ending } \\
- \text { Determination is expressed through } \\
\text { the definite article }\end{array}$ & $\begin{array}{l}\text { morphemic ending of the noun } \\
\text { - Determination is expressed } \\
\text { through the definite article }\end{array}$ \\
\hline
\end{tabular}

Attendants of Czech schools most often choose German as their second foreign language. The vast majority of Czech native speakers who learn English and German claim that the English grammar system is much easier than the grammar system of the other two languages (i.e. Czech and German) (Ondrakova

\footnotetext{
${ }^{2}$ Ondrakova et al. (2019, p. 30)
} 
\& Tauchmanova, 2018). A similar conclusion was made by Vymetálková and Milková (2019), who conducted research into effectiveness of teaching foreign languages.

We decided to focus dominantly on comparing verb forms used in the three languages. Verbs belong to the most frequently used parts of speech in all the three languages. Each of the languages researched by us has some specific features which do not occur in the other two languages. Czech verbs (and verbs in all the other Slavic languages) have the category of aspect (perfect and imperfect), English verbs can be used in continuous tenses, and German verbs create two forms of subjunctive. The absence of a particular feature in the mother tongue can result (and usually it really does) in a negative transfer and is a source of frequent errors in the process of learning other languages. On the other hand, there are also some features which are shared by more languages, and therefore they can be positively transferred into the learning process. That is why focus on specifying the similarities and differences existing in the grammar systems of the three languages with the aim to make the teaching and learning processes more effective.

\section{Research Questions}

Trying to reveal whether pre-service teachers are ready for positively transferring their already existing language skills and knowledge into processes of learning other foreign languages, we tried to answer the following three main research questions:

Are Czech learners of English and German aware of the number of verb tenses in these two foreign languages?

Are there differences in the use of verb tenses in English and German?

Are Czech learners of English and German aware of similarities in the formation of verb tenses in English and German?

\section{Purpose of the Study}

The purpose of this study is to present the findings resulting from our research into the impact of English on learning and teaching other foreign languages. Our objective is to compare the language systems of English, German and Czech and to emphasize the features shared by all the three languages and the features which are different in these languages. These similarities and differences and the level of awareness of them are of a big importance in the process of training pre-service teachers of English and German who will teach at Czech schools. The more these future teachers become acquainted with the essence and basics of the studied languages, the better they will understand their systems, and the better they will be able to present and explain the language issues to their learners in their future professional teaching career. Our efforts to train pre-service teachers in seeing deeper into the language systems are related to the fact that teaching of German as the second foreign language at Czech upper-primary schools is slowly dying out (there are efforts to teach only one foreign language - English - at Czech primary schools) and that German is consequently rather simplified and presented in the form of games at secondary schools. 


\section{Research Methods}

Two main research methods were used in our research - the quantitative and the qualitative one. The quantitative research focused on the analysis of errors obviously made due to the language interference resulting from the mother tongue knowledge and the knowledge of the first foreign language. University entrance tests in German were analysed; these written tests were completed in five consecutive years (2016, 2017, 2018, 2019 and 2020) by prospective university students wanting to major in German studies. The qualitative research was based on interviews with students carried out during the first session of the course in German morphology.

Furthermore, the professional literature and materials dealing with the issue of English and German verb tenses were researched. As the final step of the research, our finding were analysed and our conclusions were summarised.

\section{Findings}

Due to the fact that our students (i.e. future teachers of the German language at Czech upper-primary schools) did not become, during their secondary school studies, systematically aware of the verb tenses existing in the target language, starting their university studies they not only tend to be surprised by the number of tenses existing in the studied foreign languages, but they are also unable to use their knowledge and experience acquired during the process of learning their first foreign language. English and German have the same number of "basic" verb tenses and the formation of these tenses is also similar. However, differences occur in using these tenses. That is why the paper deals with the issue of both the positive transfers and the negative transfers which inevitably appear when English and German are taught as foreign languages in the Czech environment.

\subsection{Informative research at the beginning of the course in German morphology}

The course in German language morphology begins in the second term of the first academic year of studies in which students major in teaching German. In the introductory session, the students' current knowledge of and skills in German are shortly tested. The students are to translate ten sentences from Czech into German, and to submit this written translation to the teacher. The test focuses on the basic vocabulary and phrases that students are expected to master. In the same session, research in the students' awareness of the system of the target language is carried out. The students are, for example, always asked about the number of German verb tenses. Unfortunately, the results of the written tests and the oral interviews are repeatedly not good. It is obvious that students start their university studies with a low level of knowledge of the German language acquired from their secondary school studies. Concerning the knowledge of the German verb tenses, students are generally aware only of Prezens, Preteritum, Futurum and Perfektum. Some pre-service German teachers are vaguely aware of the existence of Plusquamperfectum. Hearing the teacher speaking about the existence of Futurum II, the trainees got nearly shocked. We definitely cannot be content with such a low level of knowledge of students majoring in teaching German! 


\subsection{Research into existing literature}

In reality, there are three natural time divisions: present, past and future. Referring to them, English uses the term time, German uses the term Zeit, the term čas is used in Czech. However, the grammatical reflections of the three time dimensions are different in different languages and the number of these grammatical reflections may vary as well. English uses the grammatical term tense, German uses the term Tempus (Aktionszeit), Czech uses the same term čas. The task of the tenses is not only to refer to the time dimensions of the past, present or future, but also to express the process or the completion of the event, the repetition of the event, simultaneity and the sequence of events.

Czech has a smaller number of grammatical tenses than the other two languages - there are three tenses in total (the same number as the number of the really existing times) (see Table 02). When being compared with the other two languages, which have a bigger number of tenses, Czech thus may seem not to be able to express all the details on the timeline. However, Czech, like other Slavic languages, has a category of the so-called verbal aspect; it can express the completion or non-completion of a verbal action using prefixes or suffixes.

In German, there are six grammatical tenses for expressing three time dimensions. Moreover, some grammatical tenses can refer to more real times. Plusquamperfekt, Präterium and Futur I are the so called absolute tenses and can express only one time.

English verbs also basically form six grammatical tense; dynamic verbs can also form continuous tenses. In that case, the number of grammatical tenses reaches the total number of twelve.

Table 02. All active forms of the verb "write" in the third person singular, and their Czech and German equivalents

\begin{tabular}{|l|l|l|l|}
\hline Grammar tense & English & Czech & German \\
\hline Future & $\begin{array}{l}\text { he will be writing } \\
\text { he will write }\end{array}$ & $\begin{array}{l}\text { on bude psát } \\
\text { on napíše }\end{array}$ & er wird schreiben \\
\hline Future Perfect & $\begin{array}{l}\text { he will have been writing } \\
\text { he will have written }\end{array}$ & $\begin{array}{l}\text { on bude psát } \\
\text { on bude mít napsáno }\end{array}$ & $\begin{array}{l}\text { er wird geschrieben } \\
\text { haben }\end{array}$ \\
\hline Present & $\begin{array}{l}\text { he is writing } \\
\text { he writes } \\
\text { he has been writing } \\
\text { he has written }\end{array}$ & $\begin{array}{l}\text { on píše } \\
\text { on píše } \\
\text { on napsal } \\
\text { on psal } \\
\text { on napsal } \\
\text { on psal } \\
\text { on napsal }\end{array}$ & er schreibt \\
\hline Present perfect & $\begin{array}{l}\text { he was writing } \\
\text { he wrote } \\
\text { Past }\end{array}$ & $\begin{array}{l}\text { he had been writing } \\
\text { he had written }\end{array}$ & er schrieb \\
\cline { 2 - 4 } Past perfect & & & \\
\cline { 2 - 4 } & & &
\end{tabular}

Misbalances between the number of grammatical tenses and real times are some of the sources of problems for Czech native speakers learning English and German, and, consequently, they result in frequent mistakes made in these target languages. Therefore, teachers should be able clarify the issue of verb tenses in an understandable and illustrative way.

In the efforts to clearly illustrate the relationships between individual grammatical tenses referring to the past time, Nepustil $(2005,2011)$, a Czech psychologist, came up with the terms of current past (cP), past $(P)$ and past past $(p P)$. Basically, he tried to introduce "comprehensible" terms reflecting both the formation of the tenses and the time referred to by them. 
The term of current past $(c P)$ is related to the German Perfektum, and to the English present perfect tense. It refers to events which 'have already happened but which are still related to the present time'. This connection is indicated by the word 'current' connected with the use of a present form of the auxiliary verb, the word 'past' is connected with the use of the past participle of the lexical verb (he has calculated, er hat gerechnet). The past characterizes the use of the past participles. This explanation seems very useful and fruitful since such formation does not exist in Czech:

I have not studied, so I will get a bad mark now.

Ich habe nicht gelernt, jetzt bekomme ich eine schlechte Note.

Neučil jsem se, ted' dostanu špatnou známku.

However, a problem arises when we use the word 'yesterday' in the first clause. There will be no change of the tense in the Czech or in the German sentence (but both the languages change the word order). English, however, is quite pragmatic, and the word 'yesterday' is not related to the "current past" anymore. Since the expression 'yesterday' clearly refers to the past, English uses the past tense:

Včera jsem se neučil, ted’ dostanu špatnou známku.

Gestern habe ich nicht gelernt, jetzt bekomme ich eine schlechte Note.

I did not study yesterday, so I will get a bad mark now.

The formal agreement between the English present perfect tense and the German Perfektum may seem advantageous for Czech native speakers learning these two foreign languages. In reality, however, this formal agreement is rather counterproductive, because the contexts in which these formally equivalent tenses are used are not equivalent in German and English (see the examples above). The negative interference is really frequent, and it also occurs if native German speakers are learning English.

Through the term past $(P)$ Nepustil refers to past events not related to the present time. This time dimension is expressed by the past tense in German or the simple past tense in English. Neither German nor English uses any auxiliary verb to form the given grammatical tense. However, if inversion is needed (e.g. in non-subject direct questions) or in case of negative verbal forms or short questions and short answers, English (unlike German) must use the auxiliary verb:

Er ging nach Hause. Er ging nicht nach Hause. Ging er nach Hause? Ja.

He went home. He did not go home. Did he go home? Yes, he did.

To express the past $(P)$, English also uses the past continuous tense, which refers to an activity which was in process in the past. The forms of this grammatical tense consist of the past form of the auxiliary verb 'to be' and present participle of the lexical verb. In case of inversion and negative forms it is not necessary to use any additional auxiliary verb:

Šel domů pěšky.

He was walking home. - He was not walking home. - Was he walking home?

The past past $(p P)$ is expressed by the past perfect tense (German uses the term Plusquamperfektum) and refers to a past event that began and finished before any other past event occurred. The form of $p P$ consists of the auxiliary verb in its past form and the past participle of the lexical verb (he had calculated, he had been calculating, er hatte gerechnet).

The past participle is an indefinite and fixed verb form. Thus, if this participle is a part of English and German verb forms, it is not necessary to keep in mind any changes depended on changes of the categories of Person and Number. 
Unlike one future tense existing in Czech, German and English have two kinds of tenses referring to future time - future tense (Futur I) and future perfect tense (Futur II). The future perfect tense (which does not exist in Czech) refers to future events happening before other future events. ${ }^{3}$

German expresses the "completed future" through past infinitive, and the "open future" through present infinitive. In both the cases, the present forms of the auxiliary verb 'werden' are used. Therefore, we can develop Nepustil's terminology by labelling the German Futur II (expressed through the present forms of the auxiliary verb 'wollen' and past infinitive of the lexical verb) as pF (past future), and by labelling the German Futur I (expressed through the present forms of the auxiliary verb 'wollen' and present infinitive of the lexical verb) as $c F$ (current future).

To indicate future time, English uses the verb 'will', which seems really close to the German verb 'wollen' (ich will, du willst, er will, wir wollen, ihr wollt, sie wollen). However, the meaning of these two verbs are different. Therefore, negative interference can be expected in learning both the languages, which needs to be brought to the learners' attention.

Table 03 illustrates possible ways of expressing varied future dimensions in the three languages:

Table 03. Ways of expressing the future time in Czech, German and English

\begin{tabular}{|c|c|c|c|}
\hline Language & Czech & German & English \\
\hline Time & \multicolumn{3}{|l|}{ tense } \\
\hline \multirow{5}{*}{$\begin{array}{l}\text { Future } \\
\text { (completed event) }\end{array}$} & Future & Futur II & Future simple \\
\hline & \multirow[t]{2}{*}{ Zítra napíšu ten dopis. } & \multirow[t]{2}{*}{$\begin{array}{l}\text { Morgen werde ich den } \\
\text { Brief geschrieben } \\
\text { haben. }\end{array}$} & $\begin{array}{l}\text { I will write the letter } \\
\text { tomorrow. }\end{array}$ \\
\hline & & & $\begin{array}{l}\text { Future perfect } \\
\text { simple }\end{array}$ \\
\hline & Do zítra napíšu ten dopis & $\begin{array}{l}\text { Bis Morgen werde ich } \\
\text { den Brief geschrieben } \\
\text { haben. }\end{array}$ & $\begin{array}{l}\text { I will have written the } \\
\text { letter by tomorrow. }\end{array}$ \\
\hline & & Futur I & Future continuous \\
\hline \multirow{3}{*}{$\begin{array}{l}\text { Future } \\
\text { (non-completed event) }\end{array}$} & \multirow[t]{2}{*}{ Zítra budu psát ten dopis. } & \multirow{2}{*}{$\begin{array}{l}\text { Morgen werde ich den } \\
\text { Brief schreiben. }\end{array}$} & $\begin{array}{l}\text { Tomorrow I will be } \\
\text { writing the letter. }\end{array}$ \\
\hline & & & $\begin{array}{l}\text { Future perfect } \\
\text { continuous }\end{array}$ \\
\hline & $\begin{array}{l}\text { Do zítra budu psát ten } \\
\text { dopis. }\end{array}$ & $\begin{array}{l}\text { Bis Morgen werde ich } \\
\text { den Brief schreiben. }\end{array}$ & $\begin{array}{l}\text { I will have been } \\
\text { writing the letter until } \\
\text { tomorrow.. }\end{array}$ \\
\hline
\end{tabular}

English expresses planned future activities through the present continuous tense of the given verb or the present continuous tense of the verb 'to go' followed by the infinitive of a lexical verb. Therefore, the above given Czech sentence can be also translated as: Tomorrow I am writing the letter. Tomorrow I am going to write the letter.

In addition, English expresses official scheduled and officially announced events through the present simple tense, which is also common in Czech and German:

The train leaves in half an hour.

Vlak odjiždí za půl hodiny.

\footnotetext{
${ }^{3}$ A "close future" can be expressed through present tense: Morgen fahre ich nach Prag.
} 
Der Zug fährt in einer halben Stunde ab.

The issue of expressing the future time in English is further complicated by an existing grammatical rule claiming that the auxiliary verb 'will' cannot be used in subordinate time and conditional clauses. Thus, future tenses are replaced by present tenses and future perfect tenses are replaced by present perfect tenses in these types of clauses:

Až / Jestliže bude zitra pršet, zůstaneme doma.

When / If it rains / is raining tomorrow, we will stay at home.

Až dopišeš ten dopis, zkontroluji jej.

When you have finished the letter, I will check it.

\section{Conclusion}

Although Czech, English and German are Indo-European languages, and therefore they have share some identical features, each of these languages has its own specific grammar system. The existence of different conceptions of grammatical categories in these three Indo-European languages causes problems if a person who speaks one of these languages begins to learn another one or the others of these three. On the other hand, language teachers can conveniently motivate their pupils to use their previously acquired language knowledge and skills to make the whole process of learning another language more effective.

\section{References}

Andrášová, H. (2012). Mnohojazyčnost v podmínkách českého školství se žretelem na výuku němčiny po angličtině [Multilingualism in the conditions of Czech education with regard to the teaching of German in English]. Habilitační práce. PdF MU.

Andrášová, H. (2011). Foreign Language Competences of the Czech Population: German in Comparison with Other Languages. Foreign Languages, 4, 145.

Besedova, P. (2017). Students' Attitude to Music in Foreign Language Lessons. The European Proceedings of Social \& Behavioural Sciences, 53, 71-82.

Besedova, P., Vysata, O., Mazurova, R., Kopal, J., Ondrakova, J., \& Valis, M. (2019). Classification of brain activities during language and music perception. Signal, Image and Video Processing. Springer, 2019, 1559-1567.

Dziubalska-Kollaczyk, K. (2017). Identities of English: A dynamic emergent scene [online]. http://www.viennapan.org/Presentation.pdf

Heinrichová, N. (2017). Teaching History through German Literature. The European Proceedings of Social \& Behavioural Sciences, 53, 184-193.

Nepustil, V. (2005). Gramatika. Němčina intenzivní kurz. Netradični "Nepustilova metoda" [Grammar. Intensive Course in German. "Nepustil's non-traditonal Method"]. Vladimír Nepustil.

Nepustil, V. (2011). Gramatika pro začátečníky. Angličtina intenzivní kurz. Netradiční "Nepustilova metoda" [Grammar for Beginners. Intensive Course in English. "Nepustil's non-traditonal Method"]. Vladimír Nepustil.

Ondrakova, J., \& Tauchmanova, V. (2018). Making Use of the First Foreign Language while Studying Other Foreign Languages. In SGEM International multidisciplinary scientific conference on Social sciences and arts (pp. 678-694). STEF92 Technology Ltd.

Ondrakova, J., Tauchmanova, V., \& Goebelova, Z. (2019). Verbs in English, Czech and German in Comparison (Slovesa v angličtině, češtině a němčině ve vzájemném srovnání). P. Mervart.

Vymetálková, D., \& Milková, E. (2019) Experimental Verification of Effectiveness of English Language Teaching Using My English Lab. Sustainability, MDPI, 11(5), 115. https://doi.org/10.3390/su11051357 